MATEC Web of Conferences 53, 01001 (2016)

DOI: $10.1051 /$ matecconf/20165301001

(C) Owned by the authors, published by EDP Sciences, 2016

\title{
Thermal Stressed State in Massive Concrete Structures in the Winter Building Period
}

\author{
Ivan Korotchenko ${ }^{1, a}$, Ernest Ivanov ${ }^{2}$, Kirill Semenov ${ }^{3}$ and Yuri Barabanshchikov ${ }^{4}$ \\ ${ }_{1,2,3,4}$ St. Petersburg State Polytechnical University, Institute of Civil Engineering, 29, Politechnicheskaya St., St. \\ Petersburg, 195251, Russia
}

\begin{abstract}
The article deals with issues of the thermal cracking resistance in massive concrete and reinforced concrete structures during the building period. The paper gives the calculation results of thermal stressed state in massive foundation slabs with different time organization of the thermal protection. It was found that the thermal crack resistance is fully guaranteed when the insulation is installed immediately after concrete has been placed or it has been placed with short delay. The delay can be allowed if the relative tensile strain of the concrete does not exceed the tensility limit. The acceptable delay ranges from 8 to $30 \%$ of time it takes to reach the maximum temperature in the concrete block. The surface insulation installation at the time of the temperature peak inevitably leads to the formation and development of cracks.
\end{abstract}

\section{Introduction}

In general practice the calculation of thermal fields is often based on the heat equation solution as well as thermal stresses definition [1-14].

During the building process, massive concrete and reinforced concrete structures are exposed to the temperature effect. A change in the thermal state of such structures occurs due to the heat liberation from cement hydration during the concrete hardening process, as well as outside temperature fluctuations, solar exposure, various technological factors, etc. Emerging thermal stresses may cause damage to the structural integrity [15-24, 26-30].

Due to a number of technological and manufacturing reasons, it is preferable to concrete massive foundation mats and other massive structures as a single block of equal height. However, it causes a considerable heat rise in the mass concrete as the result of an exothermic reaction during the concrete hardening. Consequently, the irregular temperature distribution arises along with the block height, which leads to the dangerous tensile strain first on the surface of the foundation slab and then in its central zones. In this regard, the winter period is especially unfavorable for construction [30].

Lowering the thermal field irregularity inside the block by raising its surface temperature prevents high tensile strain in the winter period. Both heat enclosure and an insulation layer on the concrete block are used in order to prevent high tensile strain [17, 22]. A peripheral concrete electric cable with or without minimum thermal protection is usually used as a more efficient and expensive measure. The regulation process of the hardening concrete thermal effect requires preliminary thermal

\footnotetext{
${ }^{\mathrm{a}}$ Corresponding author : saenko84@yandex.ru
} 
protection calculations or the electric heating management depending on the environmental conditions, thermal field inside the block and other factors. The papers [23, 24] deal with issues of safe replacement of passive thermal protection and lists the calculation results of electric-mode heating of massive concrete structures in the strict formulation (taking into account the influence of the hardening temperature on the thermal and deformation characteristics of concrete).

However, it is the time of the passive thermal protection installation that is also of great importance. There is an opinion that thermal protection installation with some delay is possible and even beneficial but not immediately after the placement of concrete. The time of the delay is assumed before the temperature reaches its peak in the core of the structure.

\section{Purpose of article}

The purpose of this article is to get calculation of the thermal protection installation time and research the influence of this factor on the thermal stressed state and provision of the cracking resistance of massive concrete structures. A distinctive feature of this article is to consider winter building period in the lifetime of the structure.

\section{Statement of the problem}

The justifying calculation of safe technological regimes in terms of thermal crack resistance is analyzed based on the example of 2 meters high foundation slabs mounted during the winter period.

This paper demonstrates calculation of the foundation slab thermal stressed state with the help of TERM software developed by the Institute of Civil Engineering at the St. Petersburg State Polytechnical University [18]. Considering horizontal mats sizes significantly exceed their height, we can study a one-dimensional structural model for the slab central part with the reasonable degree of accuracy. In this model, stress and temperature are functions of the vertical coordinate space.

In order to estimate the cracking resistance of the foundation slab, we would use the deformation criterion suggested by P.I. Vasiliev and provided by SP 41.13330.2012 [25]. According to this criterion, concrete elongation deformations, determined in view of the concrete creep factor and variable deformation modulus, should not exceed the ultimate concrete elongation.

\section{Base line}

As a first calculation example, we would consider the concrete hardening process B40 in the foundation slab of NPP's (Nuclear power plants) reactor hall with the cement consumption of 360 $\mathrm{kg} / \mathrm{m}^{3}$. The foundation slab is supported by the concrete bedding layer B12.5 with the grade foundation.

Thermal and physical characteristics of the concrete B40 are defined by the concrete thermal conductivity $l=2.67 \mathrm{~W} /\left(\mathrm{m} \cdot{ }^{0} \mathrm{C}\right)$ and thermal capacity $c=1.0 \mathrm{~kJ} /\left(\mathrm{kg} \cdot{ }^{0} \mathrm{C}\right)$.

The instantaneous elastic deformation modulus dependency on time is applied in accordance with N.A. Malinin's work [17]. The heat dissipation process follows the I.D. Zaporozhets equation [16].

The parameters of the equation of I.D. Zaporozhets were obtained based on the experimental data on heat dissipation of concrete.

The second example is pile foundation grillage of multifunctional building complex "Lahta Center". The concrete strength quality is B35 (modulus of elasticity is $34500 \mathrm{MPa}$ ), while the cement consumption is $340 \mathrm{~kg} / \mathrm{m}^{3}$. Piles, installed beneath the plate at regular intervals, were designed as a solid base with $10 \mathrm{GPa}$ modulus of elasticity.

The following technological conditions of concreting were considered in our calculations: the concrete mixture is placed into the shelter as a $2 \mathrm{~m}$ high block, the temperature in the shelter is $7{ }^{\circ} \mathrm{C}$, 
and the concrete mix temperature is $13{ }^{\circ} \mathrm{C}$. After concreting the surface is covered with insulation, which thickness is determined by the cracking prevention condition. Installation time of thermal insulation varied from zero (the time of placing of concrete) to the moment of reaching the maximum temperature in the structure core. These examples vary for each temperature peak reached in 6-7 days and 2-3 days respectively.

\section{Materials and methods}

\subsection{Foundation slab of NPP's reactor hall}

We calculated that the temperature peak in the slab center is achieved $6-7$ days after laying the mixture. Figure 1 shows the calculation results of the concrete elongation for series with different installation time of surface insulation and with general reduced heat transfer coefficient $\beta_{\text {red }}=4.6$ $\mathrm{W} /\left(\mathrm{m}^{2} \cdot{ }^{0} \mathrm{C}\right)$. The curves in Fig. 2 are different in the delay duration, which varies from 0 to 144 hours with a 12 hour step. Red curve corresponds to the concrete limiting extensibility [25].

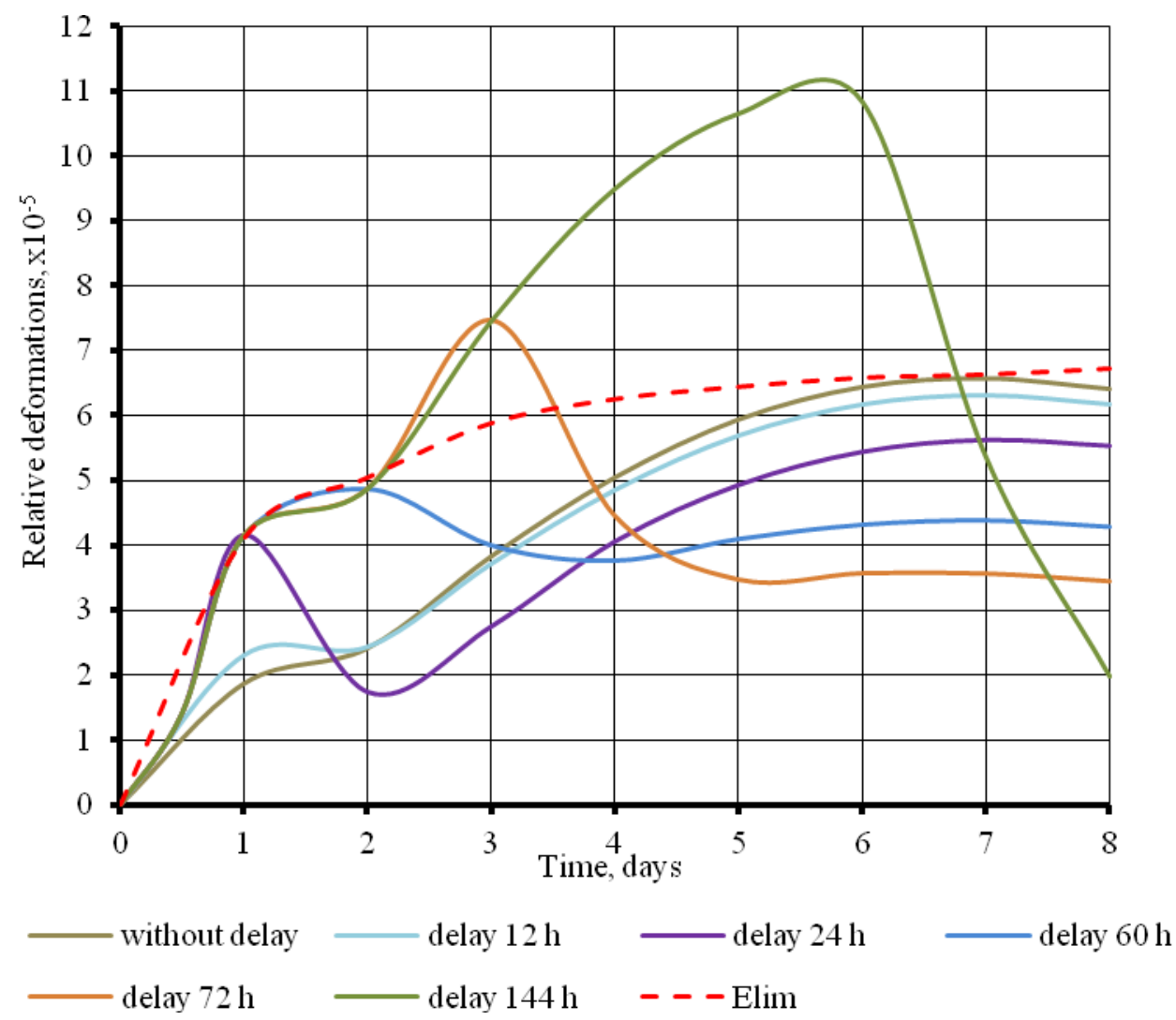

Figure. 1. Dependency the relative elongation strain on the upper surface of the slab on time for specific calculation cases.

Comparison of relative deformations to value limits shows that both the immediate insulation installation and a 12-hour delay satisfy the criterion of crack resistance. Installing insulation immediately after concrete has been placed provides greater crack resistance supply and a lesser supply after the 12-hour period. If the delay is more than 12 hours, cracks may appear on the first day. 
The longer the delay, the greater and more prolonged are the relative deformations in comparison to the value limits.

\subsection{Foundation slab of multifunctional building complex "Lahta -Center"}

We calculated that the temperature peak in the plate center is achieved 2-3 days after laying the concrete. Figure 2 shows the calculation results of the concrete relative elongation strain for series of examples with different installation time of surface insulation and with general reduced heat-transfer coefficient $\beta_{\text {red }}=2.0 \mathrm{~W} /\left(\mathrm{m}^{2} \cdot{ }^{0} \mathrm{C}\right)$. The delay duration varies from 0 to 48 hours with a 6 hour step. Red curve corresponds to the concrete limiting extensibility [25].

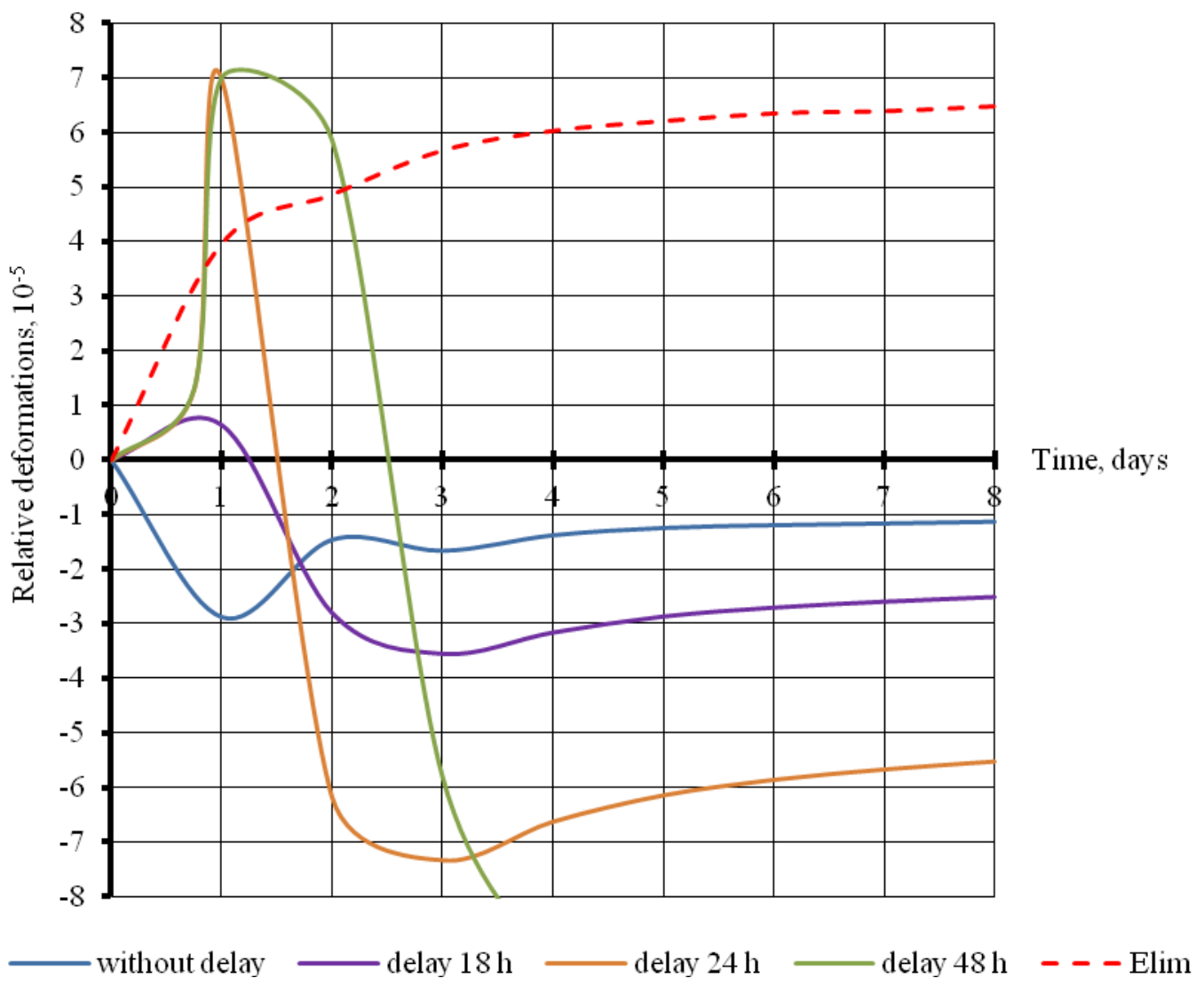

Figure 2. Dependency the relative elongation strain on the upper surface of the slab on time for specific calculation cases.

Comparison of tensile strain to value limits shows that the immediate insulation installation and a 18-hour delay satisfy the criterion of crack resistance. In cases of 24 and 48-hours delays cracks are formed on the second day. The longer the delay, the greater and more enduring are the relative deformations in comparison to the value limits.

As indicated by the NPP slab, the immediate insulation installation provides higher crack resistance during the first two days and lower resistance in case of a 18-hour delay.

\section{Results and discussion}


Investigation allows us to present the following results:

- Thermal crack resistance is fully guaranteed when insulation is installed immediately after concrete has been placed or it has been placed with small delay.

- Delay can be allowed, if the concrete relative tensile strain does not exceed its limit of tensility. In this case thermal stress state of the concrete block may be more beneficial because of lower tensile strains in the surface structure, when temperature reaches its peak in the core. This effect may take place primarily with temperature rising relatively slowly in the block.

- The acceptable delay ranges from 8 to $30 \%$ of time it takes to reach the maximum temperature in the concrete block.

\section{Conclusion}

Nowadays the construction using cast in-situ concrete is conducted almost all year round and, that especially important, in winter, when the air temperature is very low, and the temperature of the concrete core is high that leads to the formation of cracks. To avoid this it is necessary to insulate poured concrete, possibly with a certain delay, the value of which is discussed in this article. The results are particularly important in conditions of the far North, where delay in installation of insulation after concreting is especially dangerous. The results of research allow to determine the maximum acceptable delay of laying the thermal insulation on the surface of the laid concrete to avoid any cracking. As you can see, the acceptable delay should be between 8 and $30 \%$ of time it takes to reach the maximum temperature in the concrete block.

\section{References}

1. N.I. Vatin, D.V. Nemova, P.P. Rymkevich, A.S. Gorshkov, Mag. of Civ. Eng., 8, 1 (2012)

2. D.V. Petrosova, N.M. Kuzmenko, D.V. Petrosov, Mag. of Civ. Eng., 8, 31 (2013)

3. B. Kovačič, R. Kamnik, M. Premrov, Survey Review, 43 (320), 150-161 (2011)

4. D.V. Nemova, N.I. Vatin, A.S. Gorshkov, A.V. Kashabin, P.P. Rymkevich, D.N. Tseytin, Constr. of Un. Build. and Struct., 23, 93 (2014)

5. N. Lipovac, A.M., Jandriček, Prostor, 19 (2), pp. 443-455 (2011)

6. A.S. Gorshkov, P.P. Rymkevich, N.I. Vatin, (2014) Mag. of Civ. Eng., 8 , 38 (2014)

7. M.A. Platonova, N.I. Vatin, D.V. Nemova, S.A. Matoshkina, D. Iotti, I. Togo, Constr. of Un. Build. and Struct., 19, 83 (2014)

8. Z.S. Teplova, K.I. Solovyeva, D.V. Nemova, D.A. Trubina, D.V. Petrosova, Constr. of Un. Build. and Struct., 19, 96 (2014)

9. A.S. Gorshkov, N.I. Vatin, D.V. Nemova, D.A. Tarasova, App. Mech. and Mater., 725 - 726, 3 (2015)

10. N.I. Vatin, M.R. Petrichenko, D.V. Nemova, A.A. Staritcyna, D.A. Tarasova, App. Mech. and Mater., 633 -634, 1023 (2014)

11. V.A. Korsun, A.V. Korsun, App. Mech. and Mater., 725-726, 469 (2015)

12. V.A. Korsun, N.I. Vatin, A.V. Korsun, D.V. Nemova, (2014) App. Mech. and Mater., 633-634, $1013(2014)$

13. M. S. Jaafar., Adv. in Eng. Soft., 38, 886 (2007)

14. Y.G. Barabanshchikov, V.A. Sokolov, A.S. Vasiliev, M.V. Shevelev, (2012) ALITINF.: Tsem., Bet., Sukh. smes., 25, 32 (2012)

15. C.B. Aleksandrovskiy, Calculation of temperature change and humidity in terms of concerete creep in concrete and reinforced concrete structures (Moscow, 1973)

16. I.D. Zaporozhets, S.D. Okorokov, A.A. Pariyskiy, Heat Liberation by Concrete (Stroyizdat, Leningrad, 1966)

17. N.A. Malinin, Issledovaniye termonapryazhennogo sostoyaniya massivnykh betonnykh konstruktsiy s peremennymi deformativnymi kharakteristikami. Diss. na soisk. uchen. step. kan. 


\section{MATEC Web of Conferences}

teh. nauk: Spets 05.23.01 [Research of thermal stressed state of mass concrete structures with changing deformations characteristics. Cand. tech. sci. diss.] Leningrad (1977)

18. K.V. Semenov, Temperaturnoye i termonapryazhennoye sostoyaniye blokov betonirovaniya korpusa vysokogo davleniya v stroitelnyy period: Dis. na soisk. uchen. step. kan. teh. nauk: Spets 05.23.01 [Temperature and thermal stressed state of concreting blocks in a high pressure shell during the building period] Leningrad (1990)

19. Y.G. Barabanshchikov, K.V. Semenov, (2007) Pow. Tech. and Eng., 41, 197 (2007)

20. Y.G. Barabanshchikov, K.V. Semenov, M.V. Shevelev, Popul. beton., 1, 70 (2009)

21. P.I. Vasilyev, D.A. Ivanov, Yu.I. Kononov, K.V. Semenov, O.P. Starikov, Probl. of atom. sc. and tech., 1, 62. (1988)

22. L.P. Trapeznikov, Temperaturnaya treshchinostoykost massivnykh betonnykh sooruzheniy [Thermal cracking resistance of mass concrete structures] Moscow, (1986)

23. K.V. Semenov, Y.G. Barabanshchikov, Constr. of Un. Build. and Struct., 17, 125 (2014)

24. K.V. Semenov, Y.G. Barabanshchikov, App. Mech. and Mater., 725 -726, 431(2015)

25. SP 41.13330.2012. Concrete and reinforced concrete structures of hydroengineering facilities (2012).

26. M. Larson, Thermal crack estimation in early age concrete -models and methods for practical application, Doctoral Thesis, Lulea (2003)

27. S. Miyazawa, K. Koibuchi, A. Hiroshima, T. Ohtomo, T. Usui, CONCEC, 10, 1487 (2010)

28. W. Shengxing, H. Donghui, Journ. of Therm. Anal. and Calorim., 105, 171 (2011)

29. Z. Zhang, X. Zhang, X. Wang, T. Zhang, X. Zhang, App. Mech. and Mater., 94 -96, 2107 (2011)

30. Y.G. Barabanshchikov, K.V. Semenov, Pow. Tech. and Eng., 41, 197 (2007) 